\title{
Physico-chemical and microbiological investigation of the lipid from Bangladeshi fresh water fish Mystus vittatus
}

\author{
A.H. Molla, Camellia Saha, M. S. Ahsan, S. M. Talukder and M.T. Alam \\ Department of Applied Chemistry and Chemical Technology, Rajshahi University, Rajshahi, Bangladesh.
}

\begin{abstract}
This study dealt with physical, chemical and microbiological characteristics of the lipid obtained from Mystus vittatus and some nutritional properties of the fish. The fish was found to contain moisture 76.98\%, calcium $521.072 \mathrm{mg} / 100 \mathrm{gm}$, vitamin C $11.276 \mathrm{mg} / 100$ gm., lipid $1.89 \%$, and protein $10.94 \%$ respectively. The specific gravity, refractive index and co-efficient of viscosity of this lipid were recorded as 0.935 at $30^{\circ} \mathrm{C}, 1.4662$ at $30^{\circ} \mathrm{C}$ and 409.26 millipoise at $30^{\circ} \mathrm{C}$ respectively. The saponification value, iodine value, peroxide value, acid value, percentage of free fatty acid, percentage of unsaponifiable matter , Reicher-Meissel value, Polenske value and Acetyl value were found to be 218.12, 96.17, 1.79, 1.92, 0.968, 0.632, 0.932, 0.652 and 11.97 respectively. The GLC analysis revealed that the lipid is composed of palmitic acid (30.79\%), oleic acid (29.50\%), palmotelic acid (15.97\%), stearic acid (11.89\%), linoliec acid (5.43\%), myristic acid $(5.15 \%)$, lauric acid (1.07\%), arachidic acid (.57\%). The chloroform extract of this lipid showed some microbiological actively. The minimum inhibitory concentration of the extract was $0.5 \mu \mathrm{l} / \mathrm{ml}$ against Staphylococcus aureus (107 cells/ $\mathrm{ml}$ ) and $0.125 \mu \mathrm{l} / \mathrm{ml}$ against Shigella dysenteriae (107 cells/ ml).
\end{abstract}

Key words: Physico-chemical, fish nutrition, M. vittatus

\section{Introduction}

The small indigenous fresh water fish Mystus vittatus is important due to its high nutritional value in terms of lipid, protein content, the presence of micronutrients and vitamins which are not commonly available in other food. $M$ vittatus was studied to obtain detail information on their chemical composition. The study reports about the moisture, crude-fiber, drymatter, calcium, vitamin-C and protein content of the fish fillet and fatty acid composition of the lipid with its physical, chemical and microbiological characteristics.

The effectiveness of fish oil to reduce cardiovascular problems has attracted the investigators extensively to analyze the fish oils of both marine fishes and fresh water vertebrates (Kromhout et al., 1995; Herold, et al., 1996; Metcalf et al., 2007). Polyunsaturated fatty acids were found to present in high ratios in marine fish of which fatty acids of $\omega-3$ and $\omega-6$ configurations are predominant (Raclof \& Grocolas, 1994; Connor, 2001). Polyunsaturated fatty acid were reported to be an is important factor to reduce the risk of heart attack (Chin et al., 1993; Siscovick, et al., 1995; Ascherio et al., 1995; Daviglus et al., 1997)

Lipids are structural materials, reserve supply of fuels, vitamins, emulsifiers, flavours, aromatic compounds and barriers to the environment (Harris, 1989; Nestel, 1990). In the form of complex lipids, they are found in large quantities in brain and nervous tissues, indicating the important roles these substances play in the living organism (Lunberg, 1958; Goodpaster et al., 2004). The polyunsaturated fatty acids, especially linoleic acid and lenolenic acid are necessary for the proper functioning of many metabolic processes (Ascherio, 1995; Terpstra, 2004; Whigham, 2007). Beside the use in medicine and in diet, fats and lipids also have some industrial application in the manufacture of soap, paints, vernishes, and cosmetics.

\section{Materials and Methods}

Standard sizes of living M. vittatus were collected from Shaheb Bazer, Rajshahi. Only the middle portion of the body was used for nutritional studies and extraction of lipid and the content of moisture, ash, dry matter, crude fibre, calcium, vitamin-C of the fish fillet were determined by standard methods.

Lipid of this fish was extracted by Bligh and Dyer method (Bligh et al., 1959). A mixture of chloroform and methanol (2:I V/V) was used in this process. Standard methods were used for determining various physical and chemical characteristics of this lipid sample.

The fatty acid compositions of this lipid were determined by TLC and GLC analysis of the methyl ester mixture obtained from the fish lipid. At first, the lipid was saponified with alcoholic potassium hydroxide, then cooled and diluted with water. After evaporation of alcohol, the acidified aqueous mixture was extracted with ether. Ether was then removed from the extract to give fatty acid mixture. The fatty acid mixture was esterified with methanolic solution of sulphuric acid (25M, $5 \mathrm{ml}$ per gm. of acid). After esterificaton, the reaction mixture was dissolved in 
diethyl ether in a separating funnel and was washed with dilute sodium carbonate solution until the effervescence ceased. It was then washed with water, dried over anhydrous sodium sulphate and finally ether was removed to give methyl ester mixture. The methyl esters were charged on thin-layer plate $(20 \mathrm{~cm} \times 20 \mathrm{~cm}$ $\times 0.05 \mathrm{~mm}$ ) coated with silica gel $\mathrm{G}$ and the plates were developed by ascending technique with suitable solvent system. GLC experiment (Molla et al., 1994) was carried out with a "PYE UNICAM $4500 \mathrm{U}$ model gas chromatograph" equipped with a flame ionization detector.

The protein content of this fish was estimated by Micro-kjeldahl's method. At first the fish fillet was defatted, then the interfering materials were removed by $5 \%$ TCA solution. In this process, protein was estimated by titrimetric estimation of ammonia.

The micro-biological characteristics of the lipid of $M$. vittatus was determined by "Disc diffusion method" (Bauer et al., 1966). The minimum inhibitory concentration (MIC) of the lipid was carried out by serial dilution technique using a broth medium.

\section{Results and Discussion}

In the present investigation the lipid, protein, micronutrients, vitamins and other related substances in the fish fillet of $M$. vittatus were recorded. The results have been shown in the following tables.

Table-I : The nutrients in M. vittatus

\begin{tabular}{|c|c|}
\hline Moisture content & $76.49 \%$ \\
\hline Dry matter content & $23.087 \%$ \\
Ash content & $1.013 \%$ \\
Crude fiber content & $6.013 \%$ \\
Lipid content & $1.89 \%$ \\
Protein content & $10.94 \%$ \\
Calcium content & $521.072 \mathrm{mg} / 100 \mathrm{gm}$ \\
Vitamin-C content & $11.276 \mathrm{mg} / 100 \mathrm{gm}$ \\
\hline
\end{tabular}

The lipid content of the fish $M$. vittatus was 1.89 percent. The physical and chemical characteristics of the oils and fats varied within a small so that they seem to be constant. Although the chemical constants are more important to characterize an oil, but physical constants are also often capable of giving valuable information. The physical and chemical constants of the fish oil are given in tables II and III. The saponification value of the lipid of M. vittatus was found to be 218.12, when the saponification equivalent of the fish lipid was observed to be 257.19. This wascalculated from saponification value as described in the materials and methods. It is directly proportional to the average chain length of fatty acid present. Fats or oils consisting largely of $\mathrm{C}_{18}$ fatty acids, along with some myristic acid, palmitic acid, a little unsaponifiable matter and a low free acid, generally have a saponification equivalent of around 290.80; higher value indicates the presence of appreciable quantity of higher acid. The results indicate that the lipid of $M$. vittatus fish contain mainly fatty acids of $\mathrm{C}_{18}$ molecular weight along with some palmitic acid.

Table-II: The physical constants of the fish oil.

\begin{tabular}{|c|c|}
\hline Physical constant & Value \\
\hline Specific gravity & 0.935 at $30^{\circ} \mathrm{C}$ \\
Refractive index & 1.4662 at $30^{\circ} \mathrm{C}$ \\
Viscosity & 409.26 millipoise at $30^{\circ} \mathrm{C}$ \\
Energy of activation & 24.95 kjmole $^{-1}$ \\
\hline
\end{tabular}

Table - III: The chemical constants of the fish oil.

\begin{tabular}{|c|c|}
\hline Chemical constant & Value \\
\hline Saponification value & 218.1 \\
Saponification equivalent & 257.2 \\
Iodine value & 96.2 \\
Peroxide value & 1.79 \\
Acid value & 1.93 \\
Free fatty acid as oleic (\%) & 0.968 \\
Unsaponifiable matter (\%) & 0.632 \\
Reichert-Meissel value & 0.932 \\
Polenske value & 0.652 \\
Acetyl value & 11.97 \\
\hline
\end{tabular}

Iodine value gives an estimation of the degree of unsaturation and the relative amounts of unsaturated fatty acids in the triglyceride molecules of the fat. It may be suggested that the oil under investigation contains higher amounts of unsaturated fatty acids as its iodine value was calculated to be 96.17. A higher percentage of free fatty acid (above 1.5\%) is a determination or indication of unsuitability of the oil for edible purpose. So the fish oil of $M$. vittatus might be suitable for edible purposes as it contains free fatty acid less that $1.5 \%$.

The fatty acid methyl ester mixture obtained from the fish oil was subjected to TLC examination 
and their fatty acids composition were identified by

fatty acids (Table-IV).

comparing the $\mathrm{R}_{\mathrm{f}}$ values of methyl esters of standard

Table-IV: Thin layer chromatographic examination of the methyl esters mixture obtained from the lipid of Mystus vittatus.

\begin{tabular}{|c|c|c|c|c|c|c|c|c|c|c|c|}
\hline & Developing & \multicolumn{10}{|c|}{ Rf value obtained from the spot } \\
\hline \multirow{6}{*}{$\begin{array}{l}\text { Lipid of } \\
M \text {. } \\
\text { vittatus }\end{array}$} & & Methyl & Methyl & Methyl & Methyl & Methyl & Methyl & \multicolumn{4}{|c|}{ Methyl ester mixture } \\
\hline & P:E (80:20) & 0.962 & 0.931 & 0.901 & 0.933 & 0.282 & 0.885 & 0.900 & 0.936 & 0.251 & \\
\hline & P:E (60:40) & 0.978 & 0.951 & 0.952 & 0.953 & 0.323 & 0.892 & 0.731 & 0.852 & 0.950 & \\
\hline & $\begin{array}{c}\text { P:E:A } \\
(85: 15: 1)\end{array}$ & 0.844 & 0.852 & 0.805 & 0.812 & 0.319 & 0.971 & 0.679 & 0.812 & 0.850 & \\
\hline & $\begin{array}{c}\text { P:E:A } \\
(80: 20: 1)\end{array}$ & 0.810 & 0.862 & 0.880 & 0.821 & 0.419 & 0.932 & 0.792 & 0.861 & 0.722 & 0.810 \\
\hline & $\mathrm{H}: \mathrm{E}(80: 20)$ & 0.840 & 0.852 & 0.866 & 0.940 & 0.191 & 0.891 & 0.867 & 0.774 & 0.800 & \\
\hline
\end{tabular}

Using the different solvent systems, spray reagent and UV lamp, the spots were identified as oleic acid $\left(\mathrm{C}_{18.1}\right)$, linoleic acid $\left(\mathrm{C}_{18.2}\right)$, palmitic acid $\left(\mathrm{C}_{16.0}\right)$ and stearic acid $\left(\mathrm{C}_{18.0}\right)$. Fatty acid analysis of the fish lipid was carried out by GLC after trans-esterification of the glycerides to their methyl esters. The identification of fatty acid components from GLC analysis was carried out on the basis of relative retention time and were quantified by measuring the peak area in comparison with standard. The analytical data were summerised in the table V. It is evident from the table that the lipid of M. vittatus contain palmitic acid (30.79\%), oleic acid (29.50\%), palmotelic acid (15.79\%), stearic acid (11.89\%), linoleic acid (5.43\%), myristic acid (5.15\%), lauric acid (1.07\%) and arachidic acid ( 0.57\%).

Table-V: Fatty acid composition of the fatty acid methyl ester mixture derived from the lipid of $M$. vittatus (by GLC analysis).

\begin{tabular}{|c|c|c|c|}
\hline $\begin{array}{c}\text { Retention } \\
\text { time (min) }\end{array}$ & Area & Name of acid & $\begin{array}{c}\text { Relative } \\
\text { percentage (\%) }\end{array}$ \\
\hline 7.67 & 609 & Lauric & 1.07 \\
\hline 12.55 & 2933 & Myristic & 5.15 \\
\hline 17.16 & 8765 & Palmotelic & 15.39 \\
\hline 17.75 & 17520 & Palmitic & 30.79 \\
\hline 21.82 & 3091 & Linoleic & 5.43 \\
\hline 22.04 & 16783 & Oleic & 29.50 \\
\hline 22.64 & 6766 & Stearic & 11.89 \\
\hline 27.21 & 429 & Arachidic & 0.57 \\
\hline
\end{tabular}

Protein plays crucial roles in virtually all biological processes. All animals, including human, must have an adequate source of protein in order to grow and maintain themselves. The amount of protein present in $M$. vittatus was $10.94 \%$. It was determined by microkjeldahl's method.
In the microbiological investigation, it was found that the chloroform extract of the lipid of M. vittatus was active against all the gram-positive bacteria tested. The extract was also sensitive against most of the gramnegative bacteria. The minimum inhibitory concentration (MIC) of the lipid of M. vittatus was determined against two test organisms, Staphylococcus aureus and Shigella dysenteriae. The results are in table VI.

Table -VI: Minimum inhibitory concentration of the lipid of the $M$. vitattus against $S$. aureus.

\begin{tabular}{|c|c|c|c|c|}
\hline $\begin{array}{c}\text { Test } \\
\text { tube } \\
\text { number }\end{array}$ & $\begin{array}{c}\text { Nutrient } \\
\text { broth medium } \\
\text { added (ml) }\end{array}$ & $\begin{array}{c}\text { Diluted } \\
\text { solution of } \\
\text { lipid sample } \\
\boldsymbol{\mu l} / \mathbf{m l}\end{array}$ & $\begin{array}{c}\text { Inoculum } \\
\text { added } \\
(\boldsymbol{\mu l})\end{array}$ & $\begin{array}{c}\text { Observa- } \\
\text { tion }\end{array}$ \\
\hline 1 & 1 & 8.000000 & 10 & $\mathrm{NG}$ \\
2 & 1 & 4.000000 & 10 & $\mathrm{NG}$ \\
3 & 1 & 2.000000 & 10 & $\mathrm{NG}$ \\
4 & 1 & 1.000000 & 10 & $\mathrm{NG}$ \\
5 & 1 & 0.500000 & 10 & $\mathrm{NG}$ \\
6 & 1 & 0.250000 & 10 & $\mathrm{G}$ \\
7 & 1 & 0.125000 & 10 & $\mathrm{G}$ \\
8 & 1 & 0.062500 & 10 & $\mathrm{G}$ \\
9 & 1 & 0.031250 & 10 & $\mathrm{G}$ \\
10 & 1 & 0.015625 & 10 & $\mathrm{G}$ \\
\hline $\mathrm{C}_{\mathrm{s}}$ & 1 & 8.000000 & 00 & $\mathrm{NG}$ \\
$\mathrm{C}_{1}$ & 1 & 0 & 10 & $\mathrm{G}$ \\
$\mathrm{C}_{\mathrm{M}}$ & 1 & 0 & 00 & $\mathrm{NG}$ \\
\hline
\end{tabular}

$\mathrm{G}=$ Growth

NG $=$ No growth

Number of cells: $10^{7} / \mathrm{ml}$

From table VI, it was found that the MIC of the lipid of $M$. vitattus against $S$. aureus is 0.500000 $\mu \mathrm{l} / \mathrm{ml}$. 
Table -VII: Minimum inhibitory concentration of the lipid of the $M$. vitattus against $S$. dysenteriae.

\begin{tabular}{|c|c|c|c|c|}
\hline $\begin{array}{c}\text { Test tube } \\
\text { number }\end{array}$ & $\begin{array}{c}\text { Nutrient broth } \\
\text { medium added } \\
(\mathbf{m l})\end{array}$ & $\begin{array}{c}\text { Diluted } \\
\text { solution of lipid } \\
\text { sample } \mu \mathbf{l} / \mathbf{m l}\end{array}$ & $\begin{array}{c}\text { Inoculum } \\
\text { added }(\boldsymbol{\mu l})\end{array}$ & $\begin{array}{c}\text { Observ } \\
\text { ation }\end{array}$ \\
\hline 1 & 1 & 8.000000 & 10 & NG \\
2 & 1 & 4.000000 & 10 & NG \\
3 & 1 & 2.000000 & 10 & NG \\
4 & 1 & 1.000000 & 10 & NG \\
5 & 1 & 0.500000 & 10 & NG \\
6 & 1 & 0.250000 & 10 & NG \\
7 & 1 & 0.125000 & 10 & NG \\
8 & 1 & 0.062500 & 10 & $\mathrm{G}$ \\
9 & 1 & 0.031250 & 10 & $\mathrm{G}$ \\
10 & 1 & 0.015625 & 10 & $\mathrm{G}$ \\
\hline $\mathrm{C}_{\mathrm{s}}$ & 1 & 8.000000 & 00 & $\mathrm{NG}$ \\
$\mathrm{C}_{1}$ & 1 & 0 & 10 & $\mathrm{G}$ \\
$\mathrm{C}_{\mathrm{M}}$ & 1 & 0 & 00 & $\mathrm{NG}$ \\
\hline
\end{tabular}

$\mathrm{G}=$ Growth

NG $=$ No growth

It was found from the above table that the minimum inhibitory concentration of the lipid of Mystus vitattus against Shigella dysenteriae is $0.125000 \mu \mathrm{l} / \mathrm{ml}$.

From the foregoing evidences, it may be concluded that the fish Mystus vitattus along with its lipid is suitable for edible purpose. The fish and fish products are the important food sources and sources of protein in Bangladesh, which are essential in consideration to their market value. It is the basic fisheries item of Bangladesh. Lipid of the fish contains physiologically active polyunsaturated fatty acids. This is an important indication of the fish lipid to inhibit the activity of HMGCoA-reductase which is the regulatory enzyme in cholesterol biosynthesis. The cholesterol lowering effect of polyunsaturated fatty acids in fish oils have antiaggregating effect and thus reducing the risk of heart attack (Fehily et al., 1982 \& Herold et al., 1986)

\section{References}

Ascherio, A., Rimm, E.B. \& Stampfer, M.N. 1995. Dietary intake of marine n23 fatty acids, fish intake, and the risk of coronary disease among men. N. Engl. J. Med. 332: 977-82.

Bauer, A.W., Kirby, W.M. M., Sherris, J.C. \& Turck. M. 1966. Antibiotic susceptibility testing by a standardized single disk method. Amer. J. Clin. Pathol. 45: 493-496.
Bligh, E.G. \& Dyer, W.J. 1959. A rapid method of total lipid extraction and purification. Can. J. Biochem. Physiol. 37: 911-917.

Chin, J.P.F., Gust, A.P., Nestel, P.J. \& Dart, A.M. 1993. Marine oils dose-dependently inhibit vasoconstriction of forearm resistance vessels in humans. Hypertension 21: 22-28.

Connor, W.E. 2001. n-3 Fatty acids from fish and fish oil: panacea or nostrum? Am. J. Clinical Nutrition 74: 415 - 416.

Daviglus, M.L., Stamler, J., Orencia, A.J., Dyer, A.R., Liu, K., Greenland, P., Walsh, M.K., Morris, D. \& Shekelle, R.B. 1997. Fish consumption and the 30year risk of fatal myocardial infarction. $N$. Engl. J. Med. 336: 1046-1053.

Fehily, A.M., Milbank, J.E., Yarnell, J.W., Hayes, T.M., Kubiki, A.J. \& Eastham, R.D. 1982. Dietary determinants of lipoproteins, total cholesterol, viscosity, fibrinogen, and blood pressure. Am. J. Clinical Nutrition 36: 890-896.

Gerhard, G.T., Patton, B.D., Lindquist, S.A. \& Wander, R.C. 1991. Comparison of three species of dietary fish: effects on serum concentrations of low-density-lipoprotein cholesterol and apolipoprotein in normotriglyceridemic subjects. Am. J. Clinical Nutrition 54: 334-339.

Goodpaster, B.H., Stenger, V.A. Boada, F., McKolanis, T., Davis, D., Ross, R. \& Kelley D.E. 2004. Skeletal muscle lipid concentration quantified by magnetic resonance imaging. Am. J. Clinical Nutrition 79: 748-754.

Harris, W.S. 1989. Fish oils and plasma lipid and lipoprotein metabolism in humans. J. Lipid Res. 30: $785-807$.

Herold, P.M. \& Kinsella, J.E. 1986. Fish oil consumption and decreased risk of cardiovascular disease: a comparison of findings from animal and human feeding trials. Am. J. Clinical Nutrition 43: 566-598.

Kromhout, D., Feskens, E.J. \& Bowles, C.H. 1995. The protective effect of small amounts of fish on coronary heart disease mortality in an elderly population. Int. J. Epidemiol. 24: 340-345.

Lundberg, W.O. 1958. Lipids of Biologic Importance: Peroxidation Products and Inclusion Compounds of Lipids. Am. J. Clinical Nutrition 6: 601-603.

Molla, A.H., Alam, M.T. \& Rahman, M.B. 1994. The distribution pattern of fatty acids in the lipids of the bird G. Centropus sinensis sinensis. The Raj. Univ. Studies 22(B): 11-20. 
Metcalf, R.G., James, M.J., Gibson, R.A., Edwards, J.R.M., Stubberfield, J., Stuklis, R., Thomson, K.R., Young, G.D. \& Cleland, L.G. 2007. Effects of fish-oil supplementation on myocardial fatty acids in humans. Am. J. Clinical Nutrition 85: 1222-1228.

Nestel, P.J. 1990. Effects of n23 fatty acids on lipid metabolism. Annu. Rev. Nutr. 10: 149-67.

Raclot, T. \& Groscolas, R. 1994. Individual fish-oil n-3 polyunsaturated fatty acid deposition and mobilization rates for adipose tissue of rats in a nutritional steady state. Am. J. Clinical Nutrition 60: $72-78$.

Siscovick, D.S., Ragunathan, T.E., King, I, Weinmann, S., Wicklund, K.G., Albright, J., Bovbjerg, V.,
Arbogast, P., Smith, H., Kushi, L.H.,1995. Dietary intake and cell membrane levels of long-chain n23 polyunsaturated fatty acids and the risk of primary cardiac arrest. JAMA 274: 1363-7.

Terpstra, A.H.M. 2004. Effect of conjugated linoleic acid on body composition and plasma lipids in humans: an overview of the literature. Am. J. Clinical Nutrition 79: 352 - 361.

Whigham, L.D., Watras, A.C. \& Schoeller, D.A. 2007. Efficacy of conjugated linoleic acid for reducing fat mass: a meta-analysis in humans. Am. J. Clinical Nutrition 85: 1203-1211.

Manuscript received on 24.05.07, accepted on 21.07.07 